Article

\title{
Methodologies Developed for EcoCity Related Projects: New Borg El Arab, an Egyptian Case Study
}

\author{
Carmen Antuña-Rozado ${ }^{1, *}$, Justo García-Navarro ${ }^{2}$, Francesco Reda ${ }^{1}$ and Pekka Tuominen ${ }^{1}$ \\ 1 VTT Technical Research Centre of Finland Ltd., P.O. Box 1000, FI-02044 VTT, Finland; \\ francesco.reda@vtt.fi (F.R.); pekka.tuominen@vtt.fi (P.T.) \\ 2 Research Group on Sustainability in Construction and Industry giSCI-UPM, Technical University of Madrid, \\ ETSIAAB—Ciudad Universitaria, s/n, 28040 Madrid, Spain; justo.gnavarro@upm.es \\ * Correspondence: carmen.antuna@vtt.fi; Tel.: +358-40-199-3522
}

Academic Editor: Jukka Heinonen

Received: 29 April 2016; Accepted: 29 July 2016; Published: 11 August 2016

\begin{abstract}
The aim of the methodologies described here is to propose measures and procedures for developing concepts and technological solutions, which are adapted to the local conditions, to build sustainable communities in developing countries and emerging economies. These methodologies are linked to the EcoCity framework outlined by VTT Technical Research Centre of Finland Ltd. for sustainable community and neighbourhood regeneration and development. The framework is the result of a long experience in numerous EcoCity related projects, mainly Nordic and European in scope, which has been reformulated in recent years to respond to the local needs in the previously mentioned countries. There is also a particular emphasis on close collaboration with local partners and major stakeholders. In order to illustrate how these methodologies can support EcoCity concept development and implementation, results from a case study in Egypt will be discussed. The referred case study relates to the transformation of New Borg El Arab (NBC), near Alexandria, into an EcoCity. The viability of the idea was explored making use of different methodologies (Roadmap, Feasibility Study, and Residents Energy Survey and Building Consumption Assessment) and considering the Residential, Commercial/Public Facilities, Industrial, Services/Utilities, and Transport sectors.
\end{abstract}

Keywords: EcoCity; EcoCity methodologies; Egypt; feasibility study; roadmap; energy survey; energy efficiency; sustainability scenarios; $\mathrm{CO}_{2}$ emissions

\section{Introduction}

Historically, ecocity planning builds upon multiple traditions in urban planning. Among the early attempts to alleviate the negative effects of cities on the local nature and human wellbeing were the so called garden cities. Largely attributed to Ebenezer Howard and his ground-breaking book "Garden Cities of Tomorrow" [1], the garden city movement called for communities that are planned to be self-contained, limited in population, surrounded by green areas and connected to other similar cities by road and rail.

In the latter half of the 20th century, ideas about green or nature-friendly communities acquired a wider scope as more understanding about the complexities of ecological systems develops. Due to ecosystem effects, pollution and depletion of natural resources, a city's ecological impact need not only to be tempered locally, but also regionally and globally. An early example is Wolman's "urban metabolism" model that created a system of accounting for all material and commodities needed by a city [2]. McHarg, on the other hand, placed emphasis on the need to plan cities in accordance to the ecological and environmental conditions prevalent on the site [3]. 
The term "ecocity" itself was first coined in the 1980s by Richard Register through his Urban Ecology initiative and the publication of his book "Ecocity Berkeley" [4]. Also during this period the concept of sustainability had grown central in environmental thinking, epitomized by the Brundtland Commission Report [5]. In urban planning literature the key characteristics of sustainability have been summarized by Maclaren [6] as "inter-generational equity, intra-generational equity, protection of the natural environment, minimal use of non-renewable resources, economic vitality and diversity, community self-reliance, individual wellbeing, and satisfaction of basic human needs".

A new perspective on ecocity planning arose as resilience grew in importance throughout the 2000's. As Newman et al. [7] have pointed out, cities that contain healthy ecosystems and social structures can absorb disturbances and still retain their basic functions and structures. Thus the resilience view points out the benefits of ecological planning in a time when the effects of climate change are a menace to cities.

\section{VTT EcoCity Concept}

Based on the experience and knowledge accumulated in numerous EcoCity related projects, mainly Nordic and European in scope, an EcoCity concept for sustainable community and neighbourhood regeneration and development has been developed by VTT Technical Research Centre of Finland Ltd. to respond to local needs in developing countries and emerging economies. EcoCity Miaofeng (China), EcoNBC (Egypt), EcoGrad in St. Petersburg (Russia), UN Gigiri (Kenya) or MUF2013 (Tanzania) are key reference examples.

Among the main challenges faced nowadays by cities are climate change and a number of related social and technological challenges [8,9]). These include climate change mitigation and adaptation, sustainable urbanization and affordable housing, integrated planning and funding availability, access to energy, capacity building for local solutions and services, citizen empowerment and participation, or crucial cross-cutting themes like gender issues and poverty alleviation. To respond to those challenges, the VTT EcoCity concept is built around a strong collaboration with local partners in order to answer to local needs previously identified with them. The flexibility of its approach allows the development and implementation of concepts and technological solutions adapted to the local conditions and customized to varying socio-economic realities worldwide [10]. This approach can be easily linked to Roseland's affirmation that "it is at present safe to say that there is no (and perhaps should not be any) single accepted definition of ecocities or sustainable communities" [11]. Moreover, VTT's experience corroborates the need to allow communities around the world to develop and implement a local definition of sustainability, very much in line with Wong and Yuen [12].

Precisely to enable local adaptation, several methodologies have been specifically developed and applied in different case studies. The purpose of this article is to describe those and to illustrate how they can support sustainable community regeneration and development through the results of a particular case study in Egypt related to the transformation of New Borg El Arab (NBC), near Alexandria, into an EcoCity. The importance of this transformation should be understood in the context of the enormous challenges faced by Egypt with regards to human settlements and the living conditions in those. Egyptian cities are increasingly struggling with social, cultural, economic and environmental problems like high unemployment, lack of housing, water scarcity, chaotic traffic, air pollution, noise, deficient infrastructure, etc. These problems cannot be solved with the same policies and strategies that have created the underlying systemic conditions, and therefore a new basic approach is necessary [13]. Hence the need for sustainable development, ecocities and for the methodologies presented here which, as a previous step, can mobilize the Egyptian stakeholders including planners and decision makers, by creating a constructive debate on the viability of the idea (in this case study, turning NBC into an EcoCity) supported by useful facts and figures to aid decision-making, and alternative approaches and solutions for putting the idea into practice. According to Joss' analytical categories for profiling and comparing ecocity initiatives, the case study discussed here can be categorized as follows [14]: 
- Type of development: II—expansion of urban area

- Development phase: 1-pilot/planning phase

- Key implementation mode: b (integrated sustainability plan) and c (civic engagement)

Another recent study has explored the possibility of an environmentally-friendly tourist village in the vicinity of Alexandria, finding it to be an optimum location in Egypt when considering the value of greenhouse gas mitigation [15]. However, the approach proposed here is somewhat wider both in scope and methodology. The viability of the EcoCity concept was explored making use of different methodologies: Roadmap, Feasibility Study, Residents Energy Survey and Buildings Consumption Assessment [16]. In this case, "methodology" should be understood as a set of practices, quite established and systematized by now, developed and applied by VTT in order to support the development and implementation of local adaptations (in developing countries) of VTT EcoCity concept.

Finally, even though a large amount of literature exists covering the debate on ecocities, different approaches and proponents, and what are presented as practical realizations of the ecocity concept, etc., there is little relevant literature addressing the methodologies (understood as a set of practices) that can support the development and implementation of ecocities in local contexts worldwide. Therefore by putting the focus on how to achieve ecocities in practice, this article attempts to shed light on the obstacles that can be encountered, but also on the opportunities discovered, hopefully bringing depth to the practical side of the ecocity debate.

\section{Methodologies Developed for EcoCity Related Projects}

\subsection{Ecocity Roadmap}

Roadmaps have been used to both forecast and guide future developments. Modern roadmapping approaches have their roots in technological forecasting that was practised in the 1960s and 1970s to foresee the effects of fast-paced technological change on the society [17]. Simultaneously, the RAND Corporation developed the Delphi method of using expert panels for technology and business forecasting [18]. The company to first use a modern business roadmapping method was Motorola in the 1970s [19]. Bob Galvin, the CEO of Motorola at the time, defined a roadmap thus as "an extended look at the future of a chosen field of inquiry composed from the collective knowledge and imagination of the brightest drivers of change in that field" [20]. The roadmapping method used here for ecocities is close to this classical definition, but adapted for use in the context of Egypt and local sustainability issues concentrating on the case area.

Figure 1 presents the outline of the roadmapping work, adapted for VTT EcoCity concept from Kazi and Wolf [21], and applied for the first time in the project "EcoNBC, EcoCity Capacity Building in New Borg El Arab City (NBC)", a project funded by the Institutional Cooperation Instrument (ICI) under the Ministry for Foreign Affairs of Finland. The strategic roadmapping and implementation actions method focuses on the achievement of three main goals:

(1) setting key priorities (vision),

(2) developing thematic roadmaps and

(3) identifying implementation actions.

The aim of the roadmap is to match short-term and long-term goals with specific technology solutions to help meet those goals. The development of the EcoCity roadmap has three major uses: it aids in reaching a consensus about a set of needs and the technologies required to satisfy those needs, it provides a mechanism to help forecast technology developments and it functions as a framework to help plan and coordinate future technology developments. The roadmap, while developed with the particular case of NBC in mind, was intended to be applicable for the whole of Egypt. Indeed, many of the changes recommended will have to be applied on a national level.

In this case study the EcoCity roadmap was produced through a series of three consecutive and multidisciplinary workshops that included representatives of the city planning department, traffic 
planners and experts from the Egypt-Japan University of Science \& Technology (E-JUST) and VTT Technical Research Centre of Finland Ltd. Other experts from Alexandria University and Cairo University also contributed to the work. The aim was to have a mix of planning practitioners together with experts from various fields working on EcoCity topics.

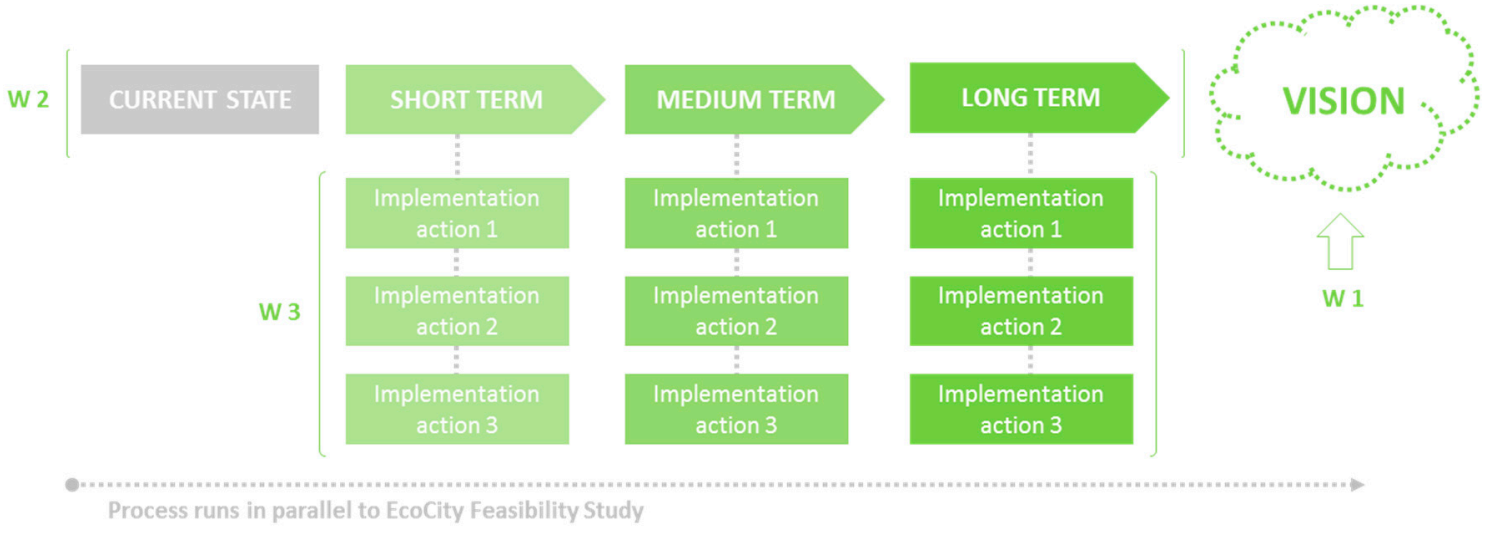

Figure 1. Simplified conceptual outline of a roadmap adapted from [21,22]. The development of the roadmap starts from defining the vision in workshop 1 (W1). Then thematic roadmaps for reaching the vision are crafted in workshop 2 (W2). Finally, detailed implementation actions are outlined in workshop 3 (W3).

The aim of the first workshop was to form a common EcoCity vision. The second workshop produced an outline for the roadmap spanning the short (1-5 years), medium (5-10 years) and long terms (10-20 years). To give an example of how problems can be divided into these timeframes, traffic problems can be alleviated in the short term with changes in ticket prices in public transport, in the medium term with the establishment of new public transport lines and in the long term with city planning. The third workshop resulted in recommendations for implementation actions to realize the envisioned roadmap. The starting point of the roadmap, termed current state in Figure 1 is provided by Hedman et al. [23]. The workshops were held in Egypt in 2013 and 2014, and commenting rounds following those events. Here the methods used in these workshops are described.

\subsubsection{Workshop 1: EcoCity Vision}

The EcoCity vision for Egypt was produced as group work using the following means of contribution:

- Task sheets were filled by the team members prior to the workshop event.

- A workshop for the EcoCity roadmap was held using the roadmapping method described by [21].

- Applicable results from the EcoCity feasibility study workshop were also included in this vision for the EcoCity roadmap.

The vision workshop consisted of three sessions. The first session was a common roundtable discussion aimed at scoping the vision work before separating into smaller groups. The second session was held in two smaller groups, where the participants wrote answers, on sticker notes, to the following questions:

- What do I like of our situation today?

- What do I not like of our situation today?

- What do I want in the future?

- What do I not want in the future?

First there were a few minutes for individual work, then writing continued as a group activity. Once the group was satisfied with the amount of answers produced, the answers were prioritized. 
This was done in two phases. First, voting was conducted, four votes per each participant, by marking with a dot the answers that people saw as the most important ones. Second, deciding as a group, the participants placed the answer notes on a line of priority ranking them from the less to more important ones. Finally, in the third session, the results of both groups were combined according to four lines of priority that had the following themes: nature, well-being, economy, society.

\subsubsection{Workshop 2: EcoCity Roadmap Outline}

The EcoCity roadmap outline was produced as group work using the following means of contribution:

- Task sheets were filled by the team members prior to the workshop event.

- A workshop for the EcoCity roadmap was held using the roadmapping method described by [21].

- Applicable results from the EcoCity feasibility study workshop were also included in this vision for the EcoCity roadmap.

The work conducted in the workshop was divided into three timeframes: short ( $2-5$ years), medium (5-10 years) and long term (10-20 years). Four small groups were formed around themes decided in the beginning of the workshop: energy; water and waste; transportation and traffic; buildings and construction. For each timeframe the groups completed the following tasks:

(1) Identify key business drivers for change and

(2) Define key actions and enablers needed for the vision to be achieved.

By business drivers it is meant things that spur growth and allow enterprises to reach success. They can mean things that create new demand, create better value to consumers, allow making more competitive products or any other factor that pushes a business forward faster. Key actions mean things that need to be done, and key enablers mean conditions that need to be present to facilitate change.

Templates for writing down the groups' findings were provided. When the groups were ready with their input, they presented them to the whole team. A round of commenting ensued where everybody had the opportunity to include their ideas to the templates with sticky notes. All input, be it from the group work or from the commenting round, are included in the results presented here.

\subsubsection{Workshop 3: Implementation Actions}

The implementation actions for the EcoCity roadmap were developed as group work using the following means of contribution:

- $\quad$ Task sheets were filled by the team members prior to the workshop event.

- A workshop for the EcoCity roadmap was held using the roadmapping method described by [21].

The work conducted in the workshop was divided into three timeframes: short ( $2-5$ years), medium (5-10 years) and long term (10-20 years). Four small groups were formed around themes decided in the beginning of the workshop: energy; water and waste; transportation and traffic; buildings and construction. For each timeframe the groups completed the following tasks:

(1) Development of Implementation Actions (IA) as individual work,

(2) Commenting and further development of IAs as group work,

(3) Implementation plan for IAs as group work, meaning placing them on a timeline and

(4) Presentation, commenting and finalizing the results, all together.

Implementation Actions mean concrete actions to help realize the roadmap. They are related to the thematic outline roadmaps developed in Workshop 2. Each IA includes a listing of the main parties responsible of realizing the action as well as a detailed definition of the action. The IAs were developed using a formalized template that worked as a checklist so that no important aspects are omitted in the description. 


\subsubsection{EcoCity Feasibility Study}

As decision makers usually face the challenge of choosing between a number of projects, they have the problem of making informed decisions between different alternatives. To answer to this need, feasibility studies have become a standard practice in various fields of business since the beginning of 1960s [24] to analyse the viability of an idea or an opportunity. As Justis and Kreigsmann [25] have pointed out, a feasibility study can "rationally uncover the strengths and weaknesses of the existing business or proposed venture, opportunities and threats as presented by the environment, the resources required to carry through, and ultimately the prospects for success". However, the activities typically associated to this kind of study are so generic in nature that they can be applied to the analysis of almost any type of idea or opportunity. According to Bryce [26], these are the elements of a good Feasibility Study (FS):

Project scope-used to define, in a concise and clear way, the idea or opportunity to be analysed.

Current analysis - used to define, understand and analyse the current method of implementation.

Requirements - these vary depending on the particular characteristics of the idea or opportunity. For example, the requirements of an EcoCity are entirely different from the requirements of a construction element.

Approach-this refers to the alternatives proposed in response to the requirements previously defined.

Evaluation-used to assess the cost effectiveness of the approach suggested.

Review - the preceding elements are assembled in the form of a FS which should be formally reviewed with all the parties involved in order to make a decision.

The methodology described here has been developed for "EcoNBC Feasibility Study. Transforming New Borg El Arab into an EcoCity", one of the main outcomes of "EcoNBC, EcoCity Capacity Building in New Borg El Arab City (NBC)" [27]. The structure of this FS was agreed in the first of a series of workshops according to the goals of the project and specific needs of NBC. However, a parallelism between the FS presented here and Bryce's FS description shown above has been established only in order to link it with the common understanding of what a FS should be. Therefore, when commented, the links with the elements previously presented will be pointed out.

New Borg El Arab (NBC) was inaugurated in 1988 and is seen as the natural extension of Alexandria, Egypt. It is regarded as the most important industrial zone in Egypt, covering an area of more than 2000 hectares and comprising about 1700 industrial facilities and institutions providing investors and owners with all needed facilities and services. At present, NBC has major development plans underway and the current population of approximately 100,000 inhabitants is expected to grow up to 750,000 inhabitants by 2032. This context offered many opportunities for the sustainable development of the city and the surrounding industry in response to the environmental, social and economic challenges that such expansion plans might arise.

Therefore, to evaluate in as much detail as possible the idea of turning NBC into an EcoCity -project scope-, a FS was carried out by a team of experts from VTT Technical Research of Finland Ltd., Egypt-Japan University of Science and Technology (E-JUST), Alexandria University and Cairo University, some of them also practitioners and planners with a vast experience and a deep understanding of the local context and the specific problems to be addressed. Based on the categories established by Abou-Zeid et al. [24] according to the function, this FS can be considered both a Technical and Economic Feasibility Study with some consideration for the social impacts derived from the implementation of the solutions proposed. The FS built on the current analysis provided by the state-of-the-art report previously developed under the abovementioned project [23]. This information together with the experience and knowledge gathered within the Finnish-Egyptian team of experts led to the definition of the FS development process shown in Figure 2 with a time horizon of 20 years.

Through a number of structured workshops held in Finland and Egypt, the experts defined a Vision-requirements-for turning NBC into an EcoCity that, from the beginning, was intended to remain ambitious but still possible to achieve in practice as long as the necessary political will and 
social commitment were in place. Such Vision evolved around three main issues of concern for each of the sectors considered, namely Residential, Commercial/Public Facilities, Industrial, Services/Utilities and Transport. To provide also a summarized view of the Vision across sectors, a "General" sector was also included. Due to their enormous relevance from an environmental point of view combined with their importance in the local context, the issues of concern chosen were Energy, Water and Waste, plus an additional category named "Other independent issues" (e.g., materials, social, etc.). Finally, quantitative and qualitative targets were set for each of the sectors in relation to the issues of concern chosen. An example can be seen in Table 1.

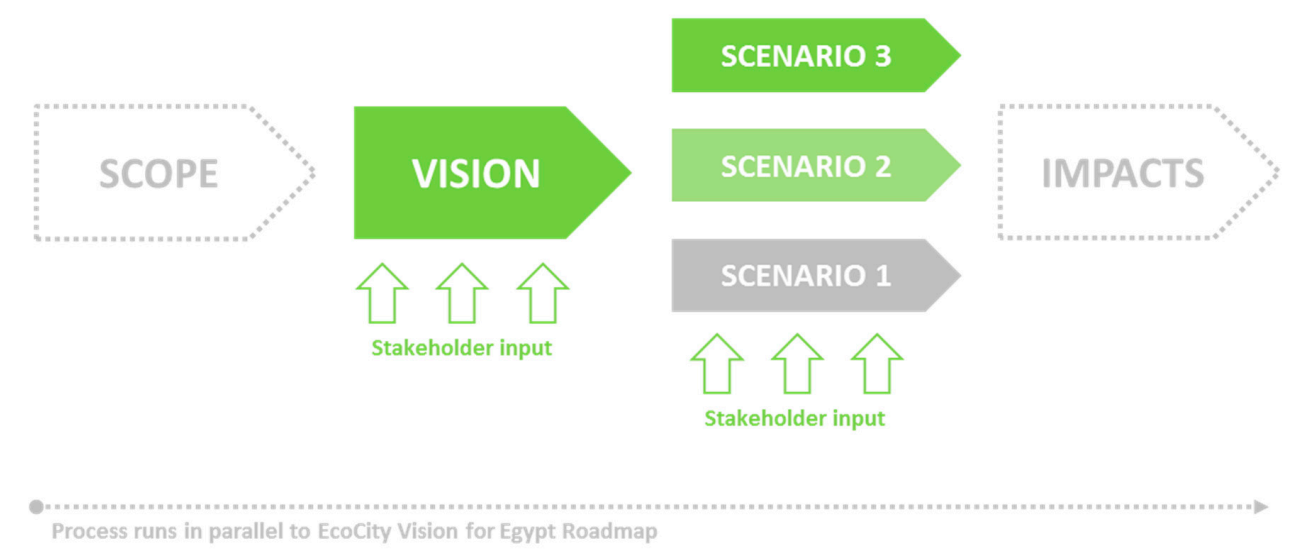

Figure 2. FS development process [27].

Table 1. Vision and targets defined for the Residential sector [27].

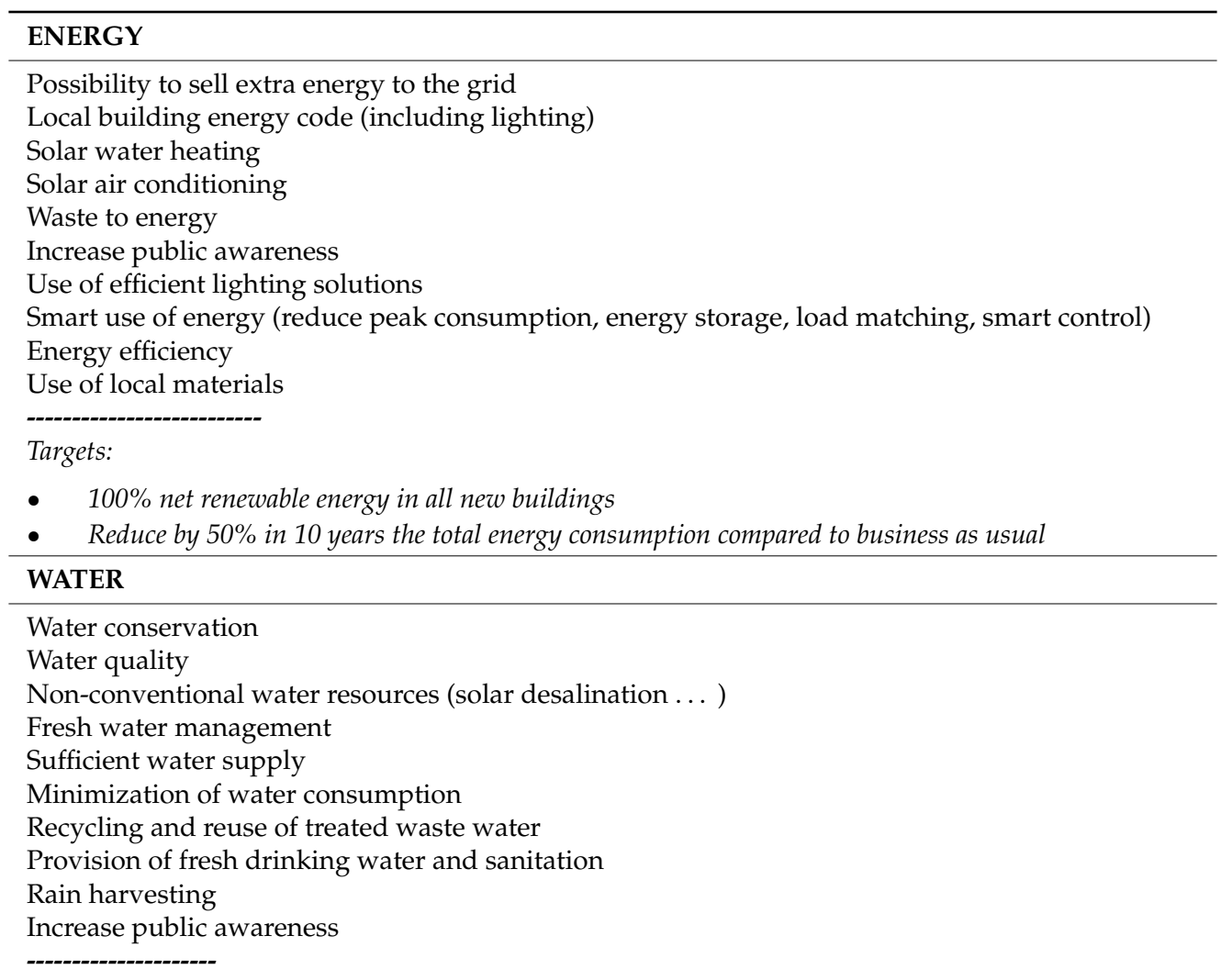


Table 1. Cont.

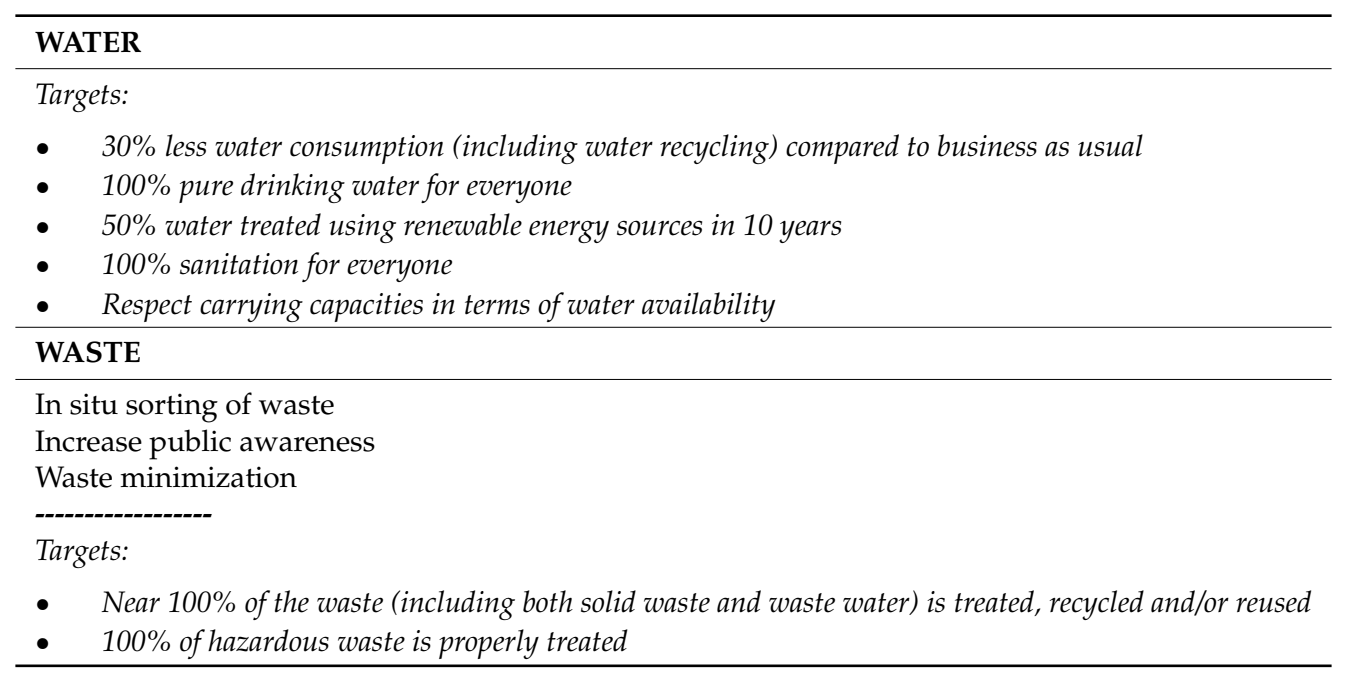

Following the definition of the Vision, and in order to evaluate the future situation of NBC in the year 2035 and its technical, environmental impacts, the scenario technique was adopted. The aim was to consider a range of possible "futures" and to provide various development strategies. The following Scenarios -approach- were agreed and developed by the Finnish-Egyptian team of experts also through a number of focused workshops:

- $\quad$ Business As Usual (BAU)

Generally speaking, this scenario implies that things will continue in the future as they are now, the evolution pattern will be the same. Therefore BAU is basically the description of the current situation, including population and economic growth, in addition to the results provided by the performance indicators proposed for a basic diagnosis. These are:

Energy consumption (kWh/year) energy source

Water consumption $\left(\mathrm{m}^{3} /\right.$ year $)$

Material consumption $(\mathrm{kg} /$ year)

Emissions ( $\mathrm{kg} \mathrm{CO}_{2}$ equivalent/year)

Wastewater $\left(\mathrm{m}^{3} /\right.$ year)

Solid waste (tonnes/year) hazardous/non hazardous

To give some more details in relation to specific sectors, for the Residential sector, BAU means no insulation, light weight envelope, single glazing, non-ventilated roofs and poor indoor air quality (low ventilation rate considering that smoking is allowed everywhere). Whereas for the Transport sector, BAU is defined as the continuation in the future of the existing travel behaviour of the year 2013/2014 according to the following assumptions: forecasted population based on the proposed Master Plan and increase rate of population, little change in the modal split to the benefit of the bus mode, and changes in the road infrastructures according to the Master Plan.

\section{- Low Investment Sustainability (LIS) scenario}

This scenario should contain primary energy efficiency measures along with the introduction of renewable energy sources and improved user behaviour regarding energy efficiency. Minimization of lighting energy consumption, as well as the consistent use of passive solutions in Residential and Commercial sectors, and the general implementation of energy audits for the Industry sector, should also be part of the LIS scenario. In relation to Water, the LIS scenario includes water conservation 
measures as well as monitoring energy and water quality inside the buildings. In relation to Waste, this scenario considers separating waste at neighbourhood and district levels.

There are a number of measures specifically related to the Transport sector like the improvement of public transport and traffic control systems, the enforcement of traffic laws, or separate lanes for different means of transportation. Other measures relate to the Industry sector like the development of low cost technologies, the optimization of material and energy flows in industrial processes or improving the skills of the employees.

In addition to this, the LIS scenario also includes other general measures like sustainable planning and design, the creation of databases for different sectors or awareness raising programmes (energy, water, waste, lifestyle ... ).

\section{- High Investment Sustainability (HIS) scenario}

In relation to Energy, the HIS scenario includes the use of advanced renewable energy technologies and solutions. For Water, this scenario considers upgrading the water distribution network, fresh water management and rain harvesting, as well as increasing the production and use of non-conventional water resources (e.g., desalination). In relation to Waste, the HIS scenario includes hazardous waste dumping sites, classification of the different industries for better common waste management, solid and liquid waste management for the Industry sector, use of non-conventional techniques for improving the added value from materials waste, $100 \%$ recycling efficiency especially for water (Zero Liquid Discharge technology).

Additionally, the HIS scenario also includes other social and economic measures with impacts on the main issues of concern selected, like improving sanitation and health, building more schools and hospitals, developing industrial ecoparks, adopting mass transport and Intelligent Traffic Systems, electric vehicles, creation of local SMEs around sustainable technologies, products and systems, etc.

Initially, these Scenarios were first defined in a general way, applicable to all sectors. Afterwards, based on the data and the tools/software available, the same Scenarios were defined more in detail for the Residential and Transport sectors, and then used as basis for energy and $\mathrm{CO}_{2}$ emissions and cost calculations respectively -evaluation-.

Feedback from local stakeholders -review- to the Vision and Scenarios thus defined was collected also through a series of workshops, and the content was refined accordingly. Local stakeholders included policy and decision makers at municipal and regional level, and also civil society (NGOs, etc.). In addition, large dissemination events were organized both in NBC and Alexandria. The suggested solutions presented in the FS were expected to assist decision makers and planners, who are concerned with improving the economic, social and environmental conditions. The FS and the alternatives it contains might be also of particular interest to researchers, engineers and scientists who could investigate them thoroughly and pursue the ideas they contain. In addition, the FS should be of considerable importance for the society of NBC as a whole, and even for the Egyptian society, since it is intended to be an example that other cities in the country could follow. On the other hand, this FS is essentially meant for investors, funding organizations and donors, who will be in a position to go through these alternatives and select the solutions which in their opinion are most relevant and applicable, taking also into account social and environmental aspects.

In addition and to complete the FS by illustrating what can be achieved in practice, it seemed necessary to show some pioneering examples from NBC and also from abroad. The examples selected from NBC correspond to some of the main local industries: textile and paper. Their inclusion is meant to highlight the already existing local initiatives towards a more sustainable industry which might hopefully inspire other industries to follow the example.

The content and methodology of the FS was aligned from the beginning, for the sake of consistency, with the EcoCity Roadmap also described here. 


\subsection{Residents Energy Survey and Building Consumption Assessment}

Understanding occupants' energy related behaviour is essential for realizing concrete EcoCity design. It represents the basis of a number of analyses: selecting appropriate novel eco-friendly technologies, assessing people acceptance of such, creating tailored operating guidelines of specific products and enabling behavioural changes towards a low energy lifestyle. All are preliminary ingredients of a successful EcoCity project implementation.

Thus, to investigate and to collect information about occupants' energy related behaviour, in case measurements of direct energy consumption patterns are not available, a suitable instrument to adopt is an energy survey. Within the EcoNBC framework a specific survey, focused on five main aspects has been used: seasonal domestic hot water usage, natural ventilation mechanisms, shading systems, home appliances utilization (including lights), heating and cooling systems and related schedule. The results of the survey served to assess the market potential of energy technologies, ensuring an easy and successful deployment, and to draw events' profiles related to occupants, which generate different energy consumption patterns along the year. Figure 3 shows the implementation process of the survey.

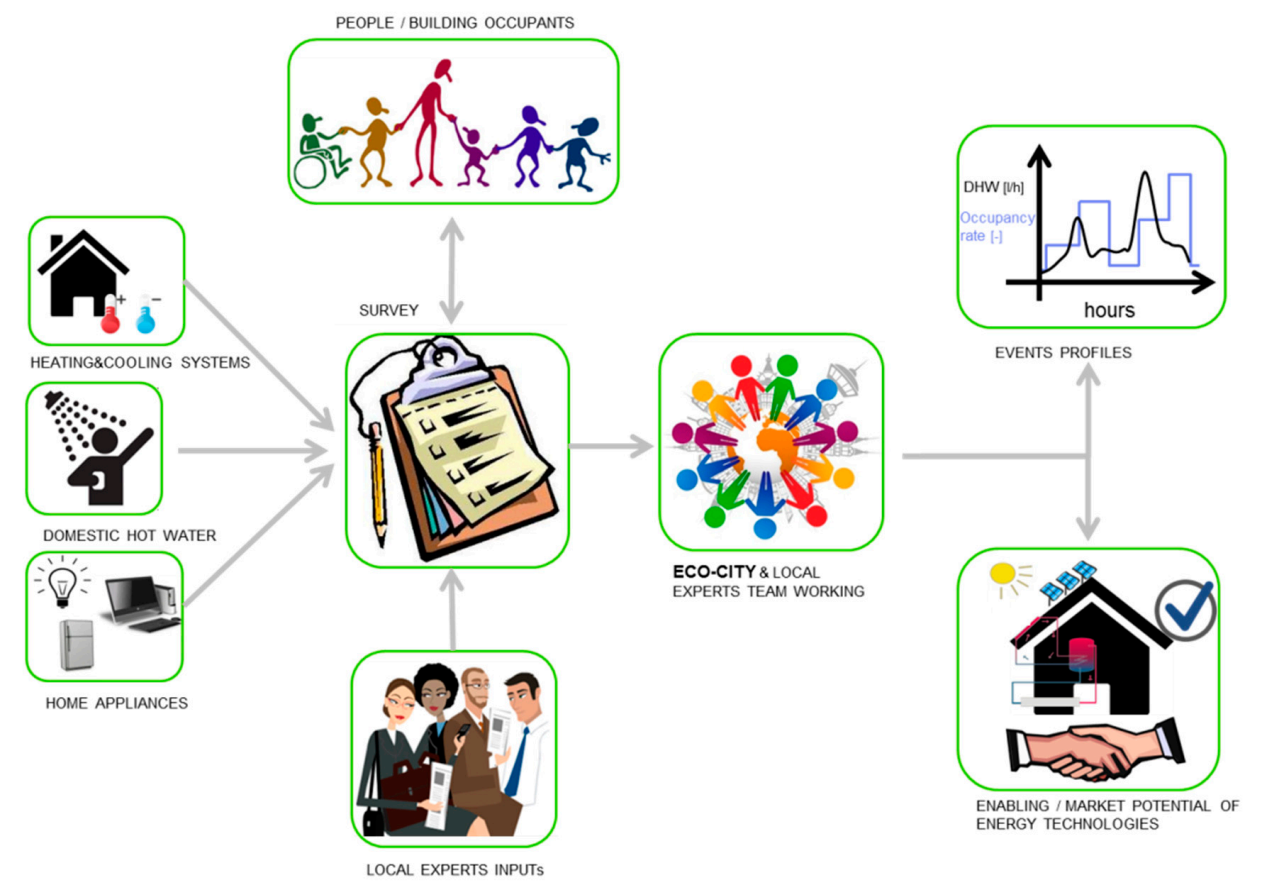

Figure 3. Implementation process of the survey [28].

The survey consists of tailored questions, created by energy and social experts to dig out fundamental information for understanding residential energy related patterns. Specifically, occupants' behaviour associated to the abovementioned aspects have been generated, evaluating amplitude, frequency and event duration. Before submitting the survey to the building occupants, local experts were involved in localizing and building a solid context around technical and cultural connected questions. Moreover, since the understanding of the survey was not granted especially for uneducated people, local trained people, belonging to NGOs, disseminated it and, in some cases, helped the targeted audience filling the survey.

VTT EcoCity and local experts (major stakeholders, public authorities and designers) defined market potential of new eco-efficient energy technologies by means of team working. This was done cross-analysing technologies' aims and technical operations with survey results, in terms of occupants' energy related patterns and needs. Involving local experts is important also in this phase for having a close sight on the local market condition and, therefore, ensuring real market penetration of the targeted technologies. Family composition and income level were considered as well 
to keep track of different behaviours along generations and wealth conditions. This allows generating different offers/scenarios, consisting of both passive and active building technologies, based on people expectancy and purchasing power.

Moreover, survey results were further processed by both VTT EcoCity and local experts to generate events' profiles related to different building energy consumption patterns, such as seasonal domestic hot water daily schedule, occupancy rate profiles along the year per each main room of the house and so on. Figure 4 depicts, as an example, the estimated domestic hot water (DHW) daily schedule in winter and summer.

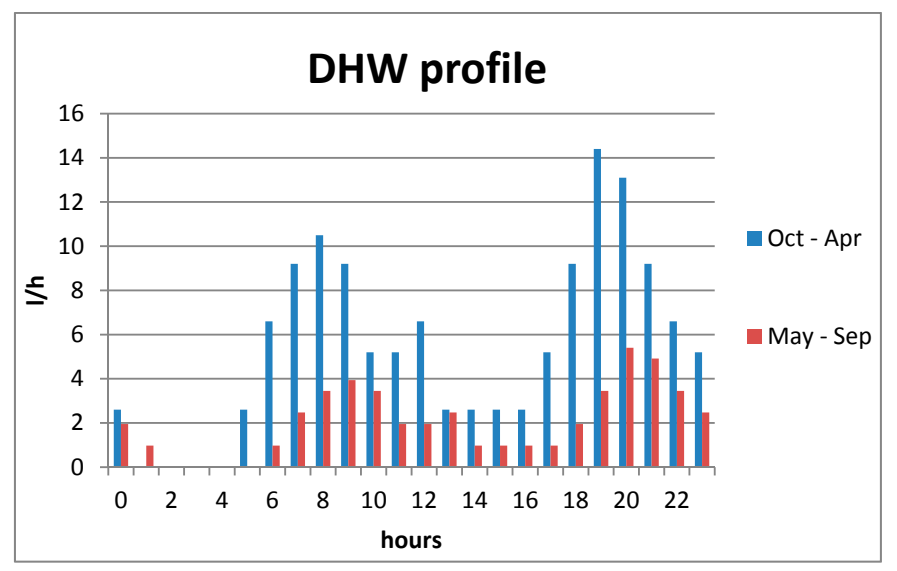

Figure 4. Domestic hot water daily schedule along the year [28].

It has to be said that defining a good sample size is a critical issue. In principle, it can be considered enough when the energy consumption patterns variance is low. However, it is not the aim of this work falling into the statistics domain. Anyhow, a good practice is to compare the results with other local studies which investigate similar aspects, if those exist.

Both survey outcomes, technologies offered and events' profiles, were used as input for assessing building energy consumption associated to each scenario. Dynamic energy modelling approach has been used to carry out the analysis. At this point it should be clarified that, since typically most of energy assessments regarding new technologies include software analysis (at least in the first stage of development), the novelty in this case lies rather the procedure for collecting input parameters for setting the simulation models as it will be described in Section 3.2.1. Figure 5 shows the Building Energy Consumption Assessment Procedure.

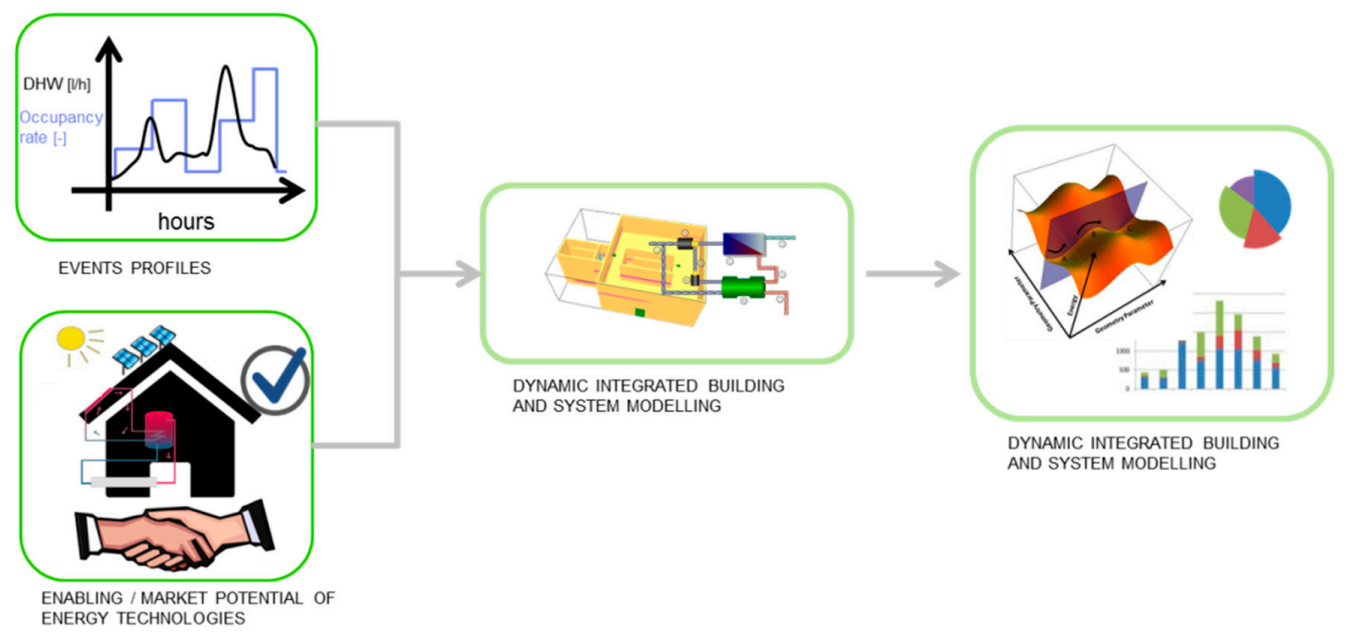

Figure 5. Building energy consumption assessment procedure [28]. 


\section{Results Concerning the Egyptian Case}

\subsection{Roadmap}

An EcoCity roadmap for Egypt was developed using a collaborative work method based on three major workshops and minor revision rounds in between. The first workshop formed a vision for EcoCities in Egypt, the second outlined thematic roadmaps for the short, medium and long terms, while the third and last workshop defined implementation actions needed to realize the roadmap. Thus the roadmap takes the form presented in Figure 1.

The EcoCity vision included issues such as food and water security, job creation, awareness and habits, sustainable use of resources, biodiversity, protection of cultural heritage, prevention of corruption, mobility, civilian rule, strategic policymaking, enforcement of regulations and policies and inclusion of all members of the society in the process. The importance of investments in human capital, health and education was underscored as an enabler of both growth and sustainability.

To realize the thematic roadmaps concrete implementation actions are recommended. They are listed in Table 2, while a more detailed presentation is given in [22].

Table 2. List of proposed implementation actions for realizing the roadmap [22].

\begin{tabular}{l}
\hline Water and Waste \\
\hline Water metering and efficient water use campaign \\
Joint water training programme \\
Waste-to-energy development programme \\
Desalination development programme \\
Campaign to reuse and recycle \\
\hline Energy \\
\hline National energy strategy \\
Energy efficiency improvement programme for businesses \\
Solar energy expansion programme \\
Smart grid action plan \\
Solar cooling development programme \\
\hline Transportation and traffic \\
\hline Policy shift to public transport \\
Multi-modal integrated public transport planning initiative \\
Privileges for car-pooling and alternative vehicles \\
Rail traffic development programme \\
Walking and cycling promotion programme \\
\hline Buildings and construction \\
\hline Healthy and safe buildings programme \\
Energy efficiency improvement programme \\
Improved building permit process \\
Quality housing expansion programme \\
\hline
\end{tabular}

A pressing issue in Egyptian cities is the need for proper housing for a growing population. Many improvements in energy efficiency and energy security do not need high investments, such as increasing the use of solar energy for heating domestic hot water. More technical details are available from [27]. New buildings should have steadily improving indoor conditions as well as well-maintained surroundings with an access to green areas for all. Preservation of natural greenery holds important value for both well-being and ecology.

Industries need to develop towards reduced emissions and energy and resource use. This process can start with energy auditing and efficiency programs for specific industries and move towards continuous improvement goals.

Transport should have less reliance on automobiles to reduce congestion, accidents, pollution and cost to families. Alternative modes of mobility should be promoted in various ways. For short distances 
walking should be made more attractive, for longer distances cycling and public transport. Similar policies can be used to promote alternative fuels and electricity in plug-in hybrids and electric vehicles.

Waste should be treated in the order of the waste hierarchy: reduce the generation of waste through more efficient processes and smart consumption choices, reuse products when they are still usable, recycle more materials, and start the use of refuse derived fuels.

In energy policy the phase-out of subsidies for electricity of fuels should be administered so that some of the saved funds are used to reduce the burden of consumers while advancing a smart energy policy that reduces environmental impacts, saves energy resources, promotes local jobs and reduces dependence on imports. In practice this means promoting public transport and making it more affordable as an alternative to cars and supporting energy efficiency and renewable energy investments in homes and businesses.

\subsection{Feasibility Study}

\subsubsection{Residential Sector}

Two investment scenarios were considered: LIS and HIS. In the first case, the design includes exclusively low cost solutions, while in the second case technologies commonly associated with Net-zero houses were included. Both cases were compared to a reference case, BAU, which includes the minimum requirements of the Egyptian energy code. In both LIS and HIS scenarios solar technologies were preferred among others because of the high level of solar irradiance in Egypt [28]. All this is shown in Table 3 below.

Table 3. List of technologies selected by local stakeholders, authorities, energy market key player [28].

\begin{tabular}{|c|c|c|c|}
\hline Technologies & Business As Usual (BAU) & $\begin{array}{l}\text { Low Investment Scenario } \\
\text { (LIS) }\end{array}$ & $\begin{array}{l}\text { High Investment Scenario } \\
\text { (HIS) }\end{array}$ \\
\hline \multirow{4}{*}{$\begin{array}{l}\text { System } \\
\text { technologies }\end{array}$} & $\begin{array}{l}\text { Incandescent } 20 \% \text { and } \\
\text { fluorescent lamp } 80 \%\end{array}$ & Fluorescent light bulbs & LEDs \\
\hline & $\begin{array}{l}\text { Free cooling system relying } \\
\text { on opening windows when } \\
\text { rooms are occupied (natural } \\
\text { ventilation only) }\end{array}$ & $\begin{array}{l}\text { Free cooling system using vents } \\
\text { (natural ventilation only) }\end{array}$ & $\begin{array}{l}\text { Mixed free cooling ventilation } \\
\text { system (through vents }+ \\
\text { mechanical ventilation) }\end{array}$ \\
\hline & - & $\begin{array}{l}\text { Unglazed solar } \\
\text { thermal collectors }\end{array}$ & Glazed solar thermal collectors \\
\hline & - & - & PV \\
\hline \multirow{4}{*}{$\begin{array}{l}\text { Envelope } \\
\text { solutions }\end{array}$} & - & External reflective paint & External reflective paint \\
\hline & $\begin{array}{l}\text { Double wall of half red-brick } \\
\text { with } 5 \mathrm{~cm} \text { air gap in between }\end{array}$ & $\begin{array}{l}\text { Insulation ( } 5 \mathrm{~cm} \text { on the ground } \\
\text { floor and the Roof, } 3 \mathrm{~cm} \text { on the } \\
\text { external walls) }\end{array}$ & $\begin{array}{l}\text { Insulation ( } 6 \mathrm{~cm} \text { on the ground } \\
\text { floor and the Roof, } 5 \mathrm{~cm} \text { on the } \\
\text { external walls) }\end{array}$ \\
\hline & - & Shading system & Shading system \\
\hline & Double glass window & Double glass window & $\begin{array}{l}\text { Double glass low-e (low thermal } \\
\text { emissivity) window }\end{array}$ \\
\hline
\end{tabular}

The study was carried out in three phases: investigation of the main behaviour patterns of occupants in relation to energy consumption, assessment of relevant technologies and, finally, energy analysis. The impacts of these scenarios were calculated in relation to $\mathrm{CO}_{2}$ emissions and costs (see Table 4). In addition, a brief expert evaluation of social factors was made.

The impact of energy and $\mathrm{CO}_{2}$ emissions were calculated by simulating in detail one reference residential building, and more specifically one apartment in the building. The simulations were done with TRNSYS software. The result was multiplied by the total number of apartment units according to the Master Plan.

The final energy consumption of LIS, around $15 \mathrm{KWh} / \mathrm{m}^{2}$ (half of the BAU), shows that a very energy efficient building can be achieved using simple and affordable envelope and energy system 
solutions. HIS scenario was sub-divided into three: HISa, $\mathrm{b}$ and $\mathrm{c}$ having different PY system configurations. For HISa the final energy consumption, around $5 \mathrm{kWh} / \mathrm{m}^{2}$, is about $65 \%$ less than that of LIS. HISb showed a final energy balance that exceeds slightly zero, around $1 \mathrm{kWh} / \mathrm{m}^{2}$, while HISc showed a negative final energy balance, around $-5 \mathrm{kWh} / \mathrm{m}^{2}$, meaning that the building produces a surplus of energy over the year.

Table 4. Annual final energy demand of the heating and cooling systems for the residential sector in New Borg El Arab City, PV produced, consumed and exported energies and final energy balance, which includes the appliances' energy consumption of each scenario [28].

\begin{tabular}{cccccc}
\hline Energy \& Emissions & BAU & LIS & HISa & HISb & HISc \\
\hline Final district energy demand (GWh) & 619.6 & 315.5 & 219.8 & 219.8 & 219.8 \\
Districts' produced PV energy (GWh) & - & - & 335.5 & 603.9 & 763.1 \\
Districts' consumed PV energy (GWh) & - & - & 114.7 & 189.7 & 205.7 \\
Districts' exported PV energy (GWh) & - & - & 116.6 & 236.2 & 343.5 \\
Final districts energy balance (GWh) & 846.2 & 542.1 & 215.1 & 20.4 & -103.0 \\
$\mathrm{CO}_{2}$ emission (1000 t) & 394.3 & 252.6 & 100.2 & 9.5 & -48.0 \\
\hline
\end{tabular}

Note: $\mathrm{CO}_{2}$ emissions are calculated based on the final district energy balance and assuming the average Egyptian emission factor for electricity for all energy use.

A Cost Effectiveness Analysis (CEA) was conducted using VTT-CEA tool on the modelled apartment building [29]. The CEA method selected was Dynamic Generation Cost (DGC), which gives as a result the price of energy saved in USD $/ \mathrm{kWh}$. The measures under consideration for LIS would have a cost of $0.21 \mathrm{USD} / \mathrm{kWh}$ for energy saved. Since at present electricity price in Egypt is heavily subsidized, it appears that LIS scenario is not economically sensible from a pure investment calculation perspective. However, further cuts in subsidies are expected which might make the investment profitable in the near future [9]. Moreover, the positive effects of reduced pollution, climate change mitigation, and decreased consumption of non-renewable resources may justify the somewhat higher cost. Finally, the results of the social impact analysis conducted are summarized in Figure 6.

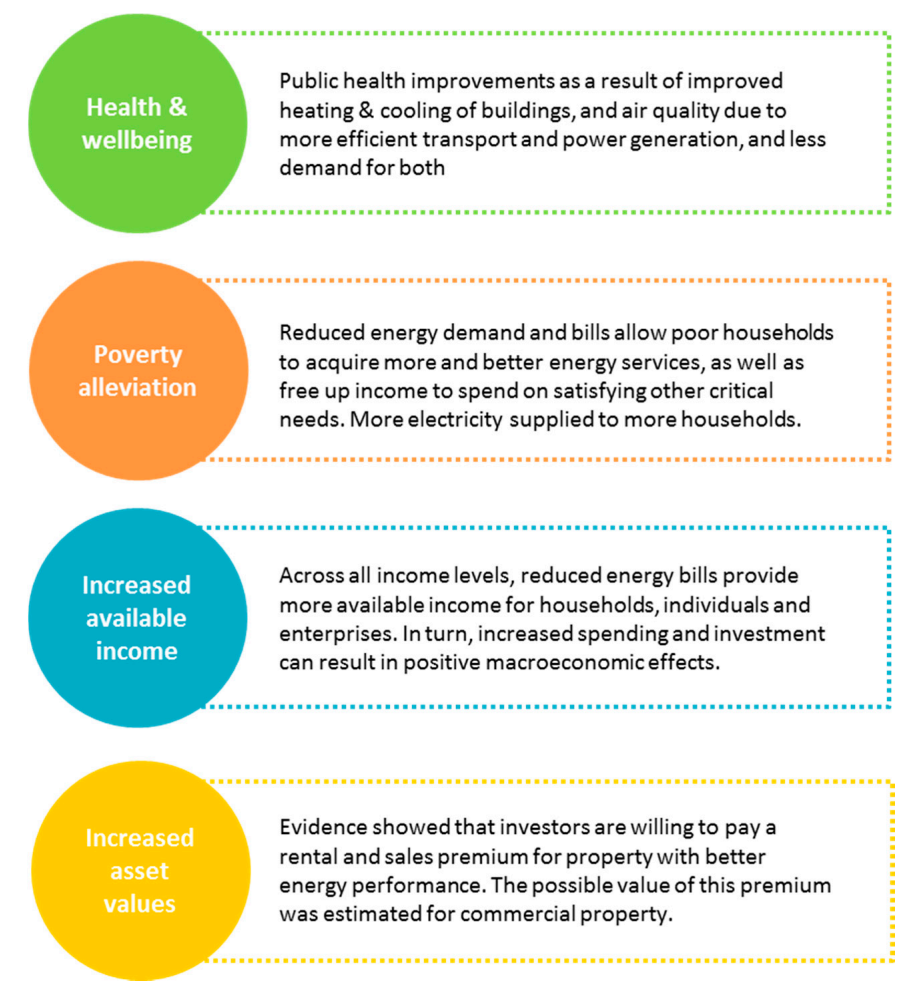

Figure 6. Social impacts derived from the scenarios proposed [27]. 


\subsubsection{Transport Sector}

Again, BAU scenario was considered the reference scenario for the Transport sector basically implying the continuation of the travel behaviour of year 2014 in the future according to the following assumptions:

- Forecasted population based on the proposed Master Plan and increase rate of population.

- Little change in the modal split to the benefit of the bus mode.

- Change in the road infrastructures based on the Master Plan.

LIS scenario included measures for saving, shifting and smoothing traffic as can be seen in Figure 7, whereas HIS scenario includes the measures of LIS scenario plus a number of others as can be seen in Figure 8.

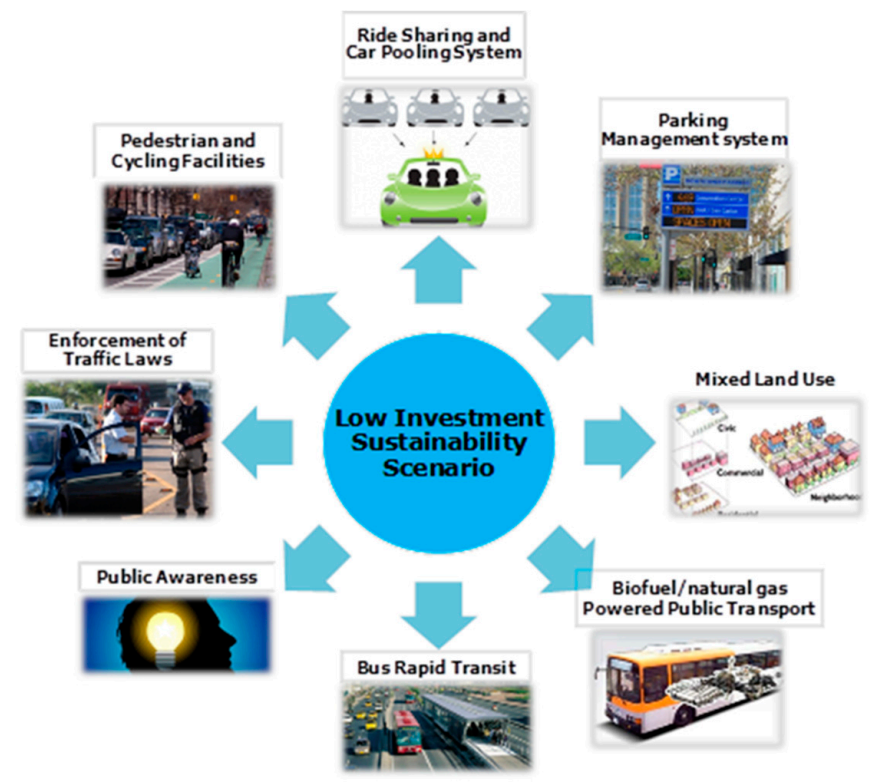

Figure 7. General description of the LIS scenario [27].

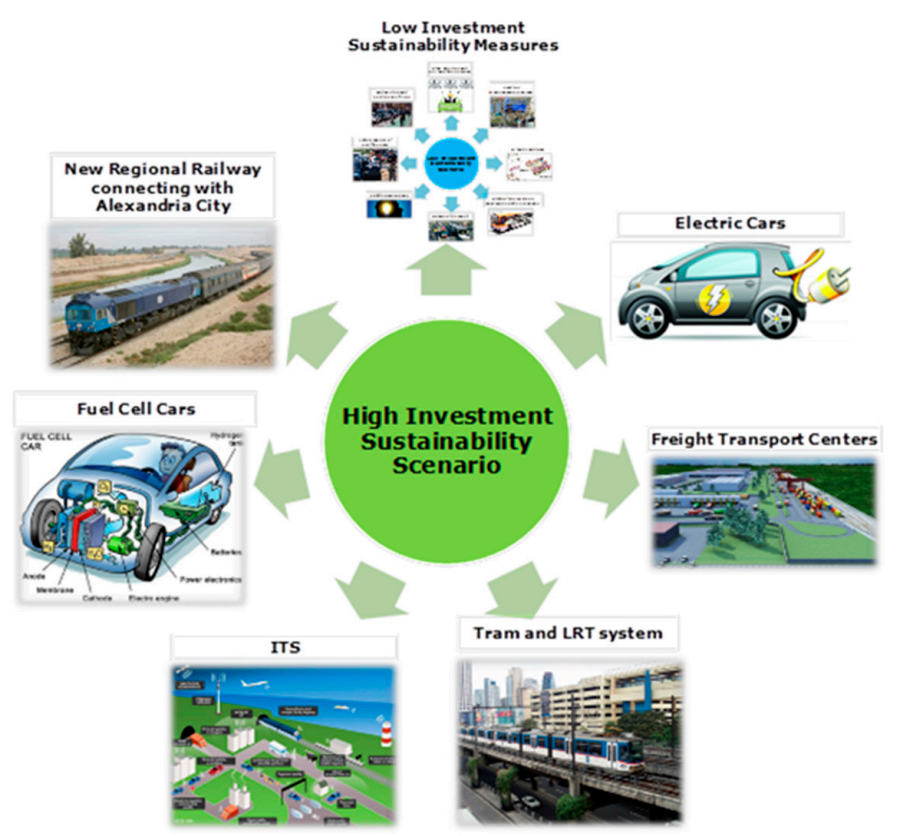

Figure 8. General description of the HIS scenario [27]. 
In relation to the impacts, the results of the energy calculations showed that the total energy consumption needed for passenger transport in New Borg El Arab under BAU scenario would reach $2.876 \mathrm{PJ}$ in 2035 with an increase rate of about $670 \%$ of the consumption in the year 2013. Under LIS and HIS scenarios, significant reductions are expected with about $37 \%$ for LIS and $58 \%$ for HIS less energy consumption compared to BAU scenario.

The annual $\mathrm{CO}_{2}$ emissions were calculated using the TraEco programme for different scenarios in the year 2015. The $\mathrm{CO}_{2}$ emissions for BAU scenario would reach 209 kilo-ton, whereas LIS and HIS scenarios would allow a decrease of respectively $40 \%$ and $62 \%$ in relation to those emitted in BAU scenario. The main reasons behind these reductions in both energy consumption and $\mathrm{CO}_{2}$ emissions are the modal shift from road transport to public transport, the improvement of the traffic conditions on the road network, and the switch from fossil fuels to electricity.

The cost analysis for different transit systems included funding agency for acquiring right of way, constructing these systems corridors and stations, procuring vehicles and installing supporting systems like fare collection, security and passenger information systems. Tables 5 and 6 illustrate the capital costs of NBC transport scenarios. There are no costs corresponding to biofuels and electric vehicles since the FS expert team did not include experts able to translate worldwide prices of such technologies to the Egyptian context.

Table 5. Low Investment Sustainability scenario costs [27].

\begin{tabular}{|c|c|c|c|c|c|}
\hline \multirow{2}{*}{ Measures } & \multirow{2}{*}{ Description } & \multicolumn{2}{|c|}{ Consultant's Experience } & \multicolumn{2}{|c|}{ Worldwide Prices } \\
\hline & & Cost Unit & $\begin{array}{l}\text { Total Cost } \\
\text { (Million LE) }\end{array}$ & Cost Unit & $\begin{array}{l}\text { Total Cost } \\
\text { (Million LE) }\end{array}$ \\
\hline $\begin{array}{l}\text { BRT Rapid } \\
\text { Transit } \\
\text { Network on the } \\
\text { main roads of } \\
\text { NBC }\end{array}$ & $\begin{array}{l}\text { BRT systems, with average route length } \\
99 \mathrm{~km} \text { covering NBC over } 98 \text { stations. }\end{array}$ & $\begin{array}{l}\text { 3.2 Million } \\
\text { LE Per km }\end{array}$ & 316.8 & $\begin{array}{l}54 \text { Million } \\
\text { LE Per km }\end{array}$ & 5,346 \\
\hline $\begin{array}{l}\text { Pedestrian and } \\
\text { Cycling } \\
\text { Facilities }\end{array}$ & $\begin{array}{l}\text { Pedestrian facilities include paths, } \\
\text { sidewalks, crosswalks, walkways, } \\
\text { stairs, ramps, and building } \\
\text { entranceways. Cycling facilities, all } \\
\text { roads should be considered cycling } \\
\text { facilities (except where cycling is } \\
\text { specifically prohibited). The cycling } \\
\text { network should be a network of streets } \\
\text { (a grid of } 0.5 \text { kilometers or less in urban } \\
\text { areas) that ensure safe bicycle access to } \\
\text { all popular destinations. Pedestrian } \\
\text { and Cycling Facilities will cover NBC } \\
\text { over length equal } 200 \mathrm{~km} \text {. }\end{array}$ & $\begin{array}{l}25,000 \mathrm{LE} \\
\text { Per km }\end{array}$ & 5.0 & $\begin{array}{l}25,000 \mathrm{LE} \\
\text { Per km * }\end{array}$ & 5.0 \\
\hline $\begin{array}{l}\text { Calming } \\
\text { Measures in } \\
\text { city centers }\end{array}$ & $\begin{array}{l}\text { Traffic calming measures are } \\
\text { engineering tools used with the goal of } \\
\text { reducing vehicle speed and improving } \\
\text { the safety of motorists, pedestrians, } \\
\text { and bicyclists. } \\
\text { Four types of measures are } \\
\text { recommended: Vertical deflections, } \\
\text { horizontal shifts, and roadway } \\
\text { narrowings are intended to reduce } \\
\text { speed and enhance the street } \\
\text { environment for non-motorists. } \\
\text { Closures (diagonal diverters, half } \\
\text { closures, full closures, and median } \\
\text { barriers) are intended to reduce } \\
\text { cut-through traffic by obstructing traffic } \\
\text { movements in one or more directions. }\end{array}$ & & 0.5 & & $0.5^{*}$ \\
\hline
\end{tabular}


Table 5. Cont.

\begin{tabular}{|c|c|c|c|c|c|}
\hline \multirow{2}{*}{ Measures } & \multirow{2}{*}{ Description } & \multicolumn{2}{|c|}{ Consultant's Experience } & \multicolumn{2}{|c|}{ Worldwide Prices } \\
\hline & & Cost Unit & $\begin{array}{c}\text { Total Cost } \\
\text { (Million LE) }\end{array}$ & Cost Unit & $\begin{array}{l}\text { Total Cost } \\
\text { (Million LE) }\end{array}$ \\
\hline $\begin{array}{l}\text { Parking } \\
\text { Management } \\
\text { system in city } \\
\text { centers }\end{array}$ & $\begin{array}{l}\text { Introduce a Parking Management } \\
\text { system for access controls and customer } \\
\text { management (such as for retail, } \\
\text { residents and employees) as well as } \\
\text { Park \& Ride concepts for commuters } \\
\text { turn the city into an inviting space. }\end{array}$ & & 1.5 & & $1.5^{*}$ \\
\hline \multicolumn{6}{|l|}{$\begin{array}{l}\text { Biofuel/natural } \\
\text { gas powered } \\
\text { public } \\
\text { transport }\end{array}$} \\
\hline \multicolumn{6}{|l|}{$\begin{array}{l}\text { Maintenance of } \\
\text { vehicles to the } \\
\text { manufacturer's } \\
\text { specifications } \\
\text { and applying } \\
\text { for Vehicle } \\
\text { Scrapping } \\
\text { Programme }\end{array}$} \\
\hline & enario Cost (Million LE) & & 3.8 & & 3.0 \\
\hline
\end{tabular}

Note: * Based on the experience of the Egyptian consultant that was part of EcoNBC expert team.

Table 6. High Investment Sustainability scenario costs [27].

\begin{tabular}{|c|c|c|c|c|c|}
\hline \multirow{2}{*}{ Measures } & \multirow{2}{*}{ Description } & \multicolumn{2}{|c|}{ Consultants Experience } & \multicolumn{2}{|c|}{ Worldwide Prices } \\
\hline & & Cost Unit & $\begin{array}{l}\text { Total Cost } \\
\text { (Million LE) }\end{array}$ & Cost Unit & $\begin{array}{l}\text { Total Cost } \\
\text { (Million LE) }\end{array}$ \\
\hline $\begin{array}{l}\text { Bus Rapid Transit } \\
\text { Network on the } \\
\text { main roads of NBC }\end{array}$ & $\begin{array}{l}\text { BRT systems, with average route } \\
\text { length } 55 \mathrm{~km} \text { covering NBC over } \\
55 \text { station. }\end{array}$ & $\begin{array}{l}\text { 3.2 Million } \\
\text { LE Per km }\end{array}$ & 176 & $\begin{array}{l}54 \text { Million } \\
\text { LE Per km }\end{array}$ & 2,970 \\
\hline $\begin{array}{l}\text { Light Rail Transit } \\
\text { Network on the } \\
\text { main roads of NBC }\end{array}$ & $\begin{array}{l}\text { Light Rail Transit, with average } \\
\text { route length } 102 \mathrm{~km} \text { covering } \\
\text { NBC over } 83 \text { station. }\end{array}$ & $\begin{array}{l}\text { 7.5 Million } \\
\text { LE Per km }\end{array}$ & 765 & $\begin{array}{l}161.25 \\
\text { Million LE } \\
\text { Per km } \\
\end{array}$ & $16,447.5$ \\
\hline $\begin{array}{l}\text { New Regional } \\
\text { Railway } \\
\text { connecting with } \\
\text { Alexandria City }\end{array}$ & $\begin{array}{l}\text { New Regional Railway with } \\
\text { average route length } 60 \mathrm{~km} \text {. }\end{array}$ & $\begin{array}{l}11.0 \text { Million } \\
\text { LE Per km }\end{array}$ & 660 & $\begin{array}{l}\text { 11.0 Million } \\
\text { LE Per km* }\end{array}$ & $660 *$ \\
\hline $\begin{array}{l}\text { Implement } \\
\text { Intelligent Traffic } \\
\text { System }\end{array}$ & $\begin{array}{l}\text { The intelligent traffic system is } \\
\text { implemented using road side } \\
\text { units (RSU) with friction } \\
\text { monitoring, vehicles with } \\
\text { environmental sensors and a } \\
\text { database for data transfer through } \\
\text { different platforms. }\end{array}$ & & & & \\
\hline $\begin{array}{l}\text { Implement freight } \\
\text { transport centers }\end{array}$ & $\begin{array}{l}\text { Implement three Freight transport } \\
\text { centers include classification } \\
\text { yards and truck terminals where } \\
\text { passengers and cargo are } \\
\text { exchanged between vehicles or } \\
\text { between transport modes. }\end{array}$ & $\begin{array}{l}\text { 50.0 Million } \\
\text { LE Per } \\
\text { Center }\end{array}$ & 150 & $\begin{array}{l}\text { 50.0 Million } \\
\text { LE Per } \\
\text { Center * }\end{array}$ & $150 *$ \\
\hline
\end{tabular}


Table 6. Cont.

\begin{tabular}{|c|c|c|c|c|c|}
\hline \multirow{2}{*}{ Measures } & \multirow{2}{*}{ Description } & \multicolumn{2}{|c|}{ Consultants Experience } & \multicolumn{2}{|c|}{ Worldwide Prices } \\
\hline & & Cost Unit & $\begin{array}{l}\text { Total Cost } \\
\text { (Million LE) }\end{array}$ & Cost Unit & $\begin{array}{l}\text { Total Cost } \\
\text { (Million LE) }\end{array}$ \\
\hline $\begin{array}{l}\text { Pedestrian and } \\
\text { Cycling Facilities }\end{array}$ & $\begin{array}{l}\text { Pedestrian facilities include paths, } \\
\text { sidewalks, crosswalks, walkways, } \\
\text { stairs, ramps, and building } \\
\text { entranceways. Cycling facilities, } \\
\text { all roads should be considered } \\
\text { cycling facilities (except where } \\
\text { cycling is specifically prohibited). } \\
\text { The cycling network should be } \\
\text { a network of streets (a grid of } \\
0.5 \text { kilometers or less in urban } \\
\text { areas) that ensure safe bicycle } \\
\text { access to all popular destinations. } \\
\text { Pedestrian and Cycling Facilities } \\
\text { will cover NBC over length } \\
\text { equal } 200 \mathrm{~km} \text {. }\end{array}$ & $\begin{array}{l}\text { 25,000 LE } \\
\text { Per km }\end{array}$ & 5 & $\begin{array}{l}25,000 \mathrm{LE} \\
\text { Per km * }\end{array}$ & $5 *$ \\
\hline $\begin{array}{l}\text { Calming Measures } \\
\text { in city centers }\end{array}$ & $\begin{array}{l}\text { Traffic calming measures are } \\
\text { engineering tools used with the } \\
\text { goal of reducing vehicle speed } \\
\text { and improving the safety of } \\
\text { motorists, pedestrians, and } \\
\text { bicyclists. Four types of measures } \\
\text { are recommended: } \\
\text { Vertical deflections, horizontal } \\
\text { shifts, and roadway narrowings } \\
\text { are intended to reduce speed and } \\
\text { enhance the street environment } \\
\text { for non-motorists. } \\
\text { Closures (diagonal diverters, half } \\
\text { closures, full closures, and median } \\
\text { barriers) are intended to reduce } \\
\text { cut-through traffic by obstructing } \\
\text { traffic movements in one or } \\
\text { more directions. }\end{array}$ & & 0.5 & & $0.5^{*}$ \\
\hline $\begin{array}{l}\text { Parking } \\
\text { Management } \\
\text { system in city } \\
\text { centers }\end{array}$ & $\begin{array}{l}\text { Introduce a Parking Management } \\
\text { system for access controls and } \\
\text { customer management (such as } \\
\text { for retail, residents and } \\
\text { employees) as well as Park \& Ride } \\
\text { concepts for commuters turn the } \\
\text { city into an inviting space. }\end{array}$ & & 1.5 & & $1.5^{*}$ \\
\hline \multicolumn{6}{|l|}{$\begin{array}{l}\text { Biofuel/natural } \\
\text { gas powered } \\
\text { public transport }\end{array}$} \\
\hline \multicolumn{6}{|l|}{$\begin{array}{l}\text { Maintenance of } \\
\text { vehicles to the } \\
\text { manufacturer's } \\
\text { specifications and } \\
\text { applying for } \\
\text { Vehicle Scrapping } \\
\text { Programme }\end{array}$} \\
\hline \multicolumn{2}{|c|}{ Scenario Cost (Million LE) } & \multicolumn{2}{|c|}{$1,758.0$} & \multicolumn{2}{|c|}{$20,234.5$} \\
\hline
\end{tabular}

Note: * Based on the experience of the Egyptian consultant that was part of EcoNBC expert team.

\section{Discussion and Conclusions}

Egypt faces at present many challenges related to fast growing cities, economic difficulties and sustainable development. EcoCities should be seen as a way to answer all three, rather than pushing to promote one over the others. The proposed implementation actions aim to reduce the 
reliance on imported energy, reduce pollution and congestion, conserve resources and valuable nature while promoting local business and jobs, improving mobility, improving the urban environment, increasing the use of renewable resources and promoting the participation of citizens. Following Joss' interpretation of the ecocity evolution, the methodologies developed to assess and support the transformation of New Borg El Arab into an EcoCity present elements of Phase I (1980s to early 1090s: grassroots movement/visions) and Phase III (2000s to present: global expansion/policy mainstreaming). Even though the Egyptian case can be considered an example of Phase III, it begins with the definition of a vision in which local experts and stakeholders had a fundamental role [30]. Perhaps the main difference is that the vision defined had to remain ambitious and yet possible - provided the necessary political and social commitment exists-in order to overcome the existing initial gap between ambition and realization that, according to Barton, characterized Phase I ecocity projects [31].

In general, one of the main obstacles encountered by the experts involved in the application of these methodologies in the case described was the unavailability of the data required or the unreliability of the existing data. As an example, even though the performance indicators listed in Section 3.2 under the BAU scenario should be feasible since they are quite basic, gathering the necessary data proved to be a considerable challenge, particularly in the case of the Industrial sector. Unfortunately, the unavailability of the data or the unreliability of the existing data is the prevalent situation throughout much of the developing world. However, this situation coexists with the demand for EcoCity Feasibility Studies, Roadmaps, etc. that can help to mobilize local stakeholders, among them decision makers and planners who are concerned with improving the environmental, economic and social conditions in their countries. Considering the urgency of these goals, such studies should still be conducted even under the existing conditions of limited availability of data. Above all, to avoid delaying the transformation towards sustainable urban development so urgently needed, particularly when considered from the wider perspective of the rapid urbanization taking place in developing countries and its impacts on climate change. In this context, making assumptions, which of course should have solid grounds and be adequately justified, was found necessary by the experts involved in the FS.

To be more precise, one of the first decisions made by the expert team was to define the Vision (including associated targets) and the three scenarios explained in Section 2.1.4 (BAU, LIS and HIS) for each of the sectors considered (Residential, Commercial/Public facilities, Industrial, Services/Utilities, Transport) plus the "General" sector. However, for the calculation of the impacts in terms of energy, $\mathrm{CO}_{2}$ emissions and costs, of the defined scenarios, accurate data is needed. In this case, valid and reliable data was only available for the Residential and Transport sectors, therefore it was decided that the impacts mentioned would be calculated only for these two sectors for the sake of consistency. But even if most of the data required was available, still some assumptions had to be made. As an example, for the Residential sector CEA calculation, it was assumed that in LIS scenario on average one workday annually is used by an unskilled worker cleaning the rooftop systems, and one workday by skilled professionals, such as an electrician, on system check-ups, totalling 40 USD/a using typical local costs.

Therefore, one of the main recommendations is to draw the attention of all involved stakeholders towards the importance of making the data available in order to support sustainable development. For example, in the case of NBC Industrial sector, it has been advised to start by collecting basic information in relation to the following key aspects:

- How many plants are there in the city? What is the expected growth of that number?

- How many employees are there? What is the expected growth of that number?

- How developed is the technology used?

- How skilled are the employees? What are the required skills?

- What kinds of energy sources are used? What is the distribution of these?

- Water supply and water treatment. 
More specifically about the scenarios proposed and evaluated for the Residential sector, it is evident that the impact would be considerable if these scenarios would be applied to the whole city of New Borg El Arab. Savings up to $605.7 \mathrm{GWh}$ could be achieved and $282.2 \mathrm{~K}$ tons of $\mathrm{CO}_{2}$ emissions could be avoided. This amounts to the total $\mathrm{CO}_{2}$ emissions of 117,853 Egyptians. This can be considered high impact since the city is planned to host 750,000 inhabitants. Only the savings achieved in the Residential sector would enable $15 \%$ of the population to live totally "carbon free", theoretically calculated. The figure becomes even bigger when combined with sustainability actions in other sectors.

In conclusion, very low energy and net zero energy buildings have been designed in line with the local context, using envelope solutions to lower their energy needs and renewable systems to achieve a near zero or a negative final energy balance. It is also important to stress once more that considerable reduction in energy demand can be achieved with relatively low cost solutions, as it has been also corroborated by research in Southern European countries with similar climates. As an example, the correct design of openings can by itself contribute significantly to improve the thermal performance of a building [32]. Ideally, this study along with others should attract the interest of local and central administrations for planning and building new eco-friendly residential districts that include very energy efficient buildings.

In addition to the previous, there is also an enormous potential for developing locally adapted systems and solutions for energy retrofitting and renovation of the existing built stock that would at the same time decrease the energy demand and improve the quality of the indoor living and working environment. Moreover, when applied to buildings with poor accessibility (lack of lifts or ramps), different construction pathologies and service facilities in need of upgrading, substantial improvements in citizens' quality of life and social inclusion of disadvantaged people can be achieved. And as a consequence, the real estate value of those buildings is also increased [33].

As a variety of ecocity initiatives are currently under development worldwide, adequate tools and practices for their implementation are becoming increasingly important. The methodologies presented here, developed in collaboration with local experts and stakeholders, aim at contributing to the practical debate on the mainstreaming of ecocities. They can also complement the definition of ecocity indicators proposed by authors like Joss as a tool to support governance and a necessary step towards establishing common standards for urban sustainability [34].

VTT's experience in different EcoCity projects shows that fruitful collaboration with local actors is the basis for the successful development of locally adapted solutions. It has been also observed that the younger generations in Egypt are increasingly aware of the importance of sustainable development and were eager to take part in a number of activities organized within EcoNBC project. Combined with their fondness for new technologies, ICT and social media, this offers many opportunities for creating employment through green businesses and jobs. This is a crucial issue in countries like Egypt where there is a pressing need to provide employment for the youth. However, tapping into the potential described requires facilitation skills together with an understanding of and a constructive approach to cultural differences.

To finalize, the conclusions that can be drawn from this experience can be summarized as follows:

- Adequate methodologies are needed to support EcoCity development in response to the challenges faced nowadays by communities and neighbourhoods worldwide.

- Their adequateness depends on their capacity to provide suitable locally adapted solutions, and to that end collaboration with local actors is of particular importance.

- Fruitful collaboration with local actors requires strong facilitation skills and understanding of cultural differences.

- Very often these methodologies require certain data that, even if basic, are not available (or will not be released by those that could provide them), or are unreliable. Therefore, a number of assumptions might be necessary to overcome this situation.

- The results show that affordable solutions, locally available and relatively easy to implement, can have a very positive impact in the final energy balance. 
- The potential for substantially increasing the energy efficiency, not only in new urban developments but also in existing neighbourhoods is enormous, and offers plenty of opportunities for creating employment through green businesses and jobs.

Acknowledgments: This research has been carried within the project "EcoNBC, EcoCity Capacity Building in New Borg El Arab City (NBC)" funded by the Institutional Cooperation Instrument (ICI) under the Ministry for Foreign Affairs of Finland. The costs to publish this article in open access are covered by VTT Technical Research Centre of Finland Ltd. The authors wish to thank the Ministry for Foreign Affairs of Finland, and especially their colleagues from Sustecon Ltd., Egypt-Japan University of Science and Technology (E-JUST), Alexandria University and Cairo University.

Author Contributions: All the authors from VTT conceived and designed the methodologies (or their adaptation), and managed their development process. Carmen Antuña-Rozado managed the Feasibility Study development process; Francesco Reda developed the residents' survey and contributed to the part of the Feasibility Study related to the Residential sector; Pekka Tuominen managed the Roadmap development process and contributed to the Cost Effectiveness Analysis within the Feasibility Study. Justo García-Navarro from UPM has critically reviewed the manuscript and provided useful references linking the methodologies and the Egyptian case study to relevant research conducted in Southern Europe, particularly in Spain, in areas with similar climatic conditions.

Conflicts of Interest: The authors declare no conflict of interest.

\section{References}

1. Howard, E. Garden Cities of Tomorrow; Swan Sonnenschein \& Co.: Bath, UK, 1898.

2. Wolman, A. The Metabolism of Cities. Sci. Am. 1965, 213, 179-190. [CrossRef] [PubMed]

3. McHarg, I. Design with Nature; Natural History Press: New York, NY, USA, 1969.

4. Register, R. Ecocity Berkeley: Building Cities for a Healthy Future; North Atlantic Books: Berkeley, CA, USA, 1987.

5. Brundtland Commission. Our Common Future; Oxford University Press: Oxford, UK, 1987.

6. Maclaren, V. Urban Sustainability Reporting. J. Am. Plan. Assoc. 1996, 62, 184-202. [CrossRef]

7. Newman, P.; Beatley, T.; Boyer, H. Resilient Cities; Island Press: Washington, DC, USA, 2009.

8. Grafakos, S.; Enseñado, E.; Flamos, A.; Rotmans, J. Mapping and Measuring European Local Governments' Priorities for a Sustainable and Low-Carbon Energy Future. Energies 2015, 8, 11641-11666. [CrossRef]

9. Tuominen, P.; Klobut, K.; Tolman, A.; Adjei, A.; de Best-Waldhober, M. Energy savings potential in buildings and overcoming market barriers in member states of the European Union. Energy Build. 2012, 51, 48-55. [CrossRef]

10. Huovila, P.; Antuña, C. EcoCities, VTT's concept for sustainable community and neighbourhood regeneration and development. In Proceedings of the 2nd World Sustainability Forum (WSF-2012), Sciforum Electronic Conferences Series, 1-30 November 2012.

11. Roseland, M. Dimensions of the eco-city. Cities 1997, 14, 197-202. [CrossRef]

12. Wong, T.-C.; Yuen, B. Eco-City Planning: Policies, Practice and Design; Springer: Heidelberg, Germany, 2011.

13. Goell, E.; El-Lahham, N.; Hussen, W.; El-Khishin, S.; Soliman, S. Sustainable Cities in Egypt. Learning from Experience: Potentials and Preconditions for New Cities in Desert Areas; The Egyptian Cabinet Information and Decision Support Center, Center for Future Studies: Cairo, Egypt, 2009; Volume 77.

14. Joss, S. Eco-cities: A global survey 2009. WIT Trans. Ecol. Environ. 2010, 129, 239-250.

15. Diab, F.; Lan, H.; Zhang, L.; Ali, S. An Environmentally-Friendly Tourist Village in Egypt Based on a Hybrid Renewable Energy System-Part One: What Is the Optimum City? Energies 2015, 8, 6926-6944. [CrossRef]

16. Hedman, Å.; Huovila, P.; Tuominen, P.; Reda, F.; Antuña, C.; Jantunen, J.; Pajula, T.; ElMahgary, Y.; El-Shazly, A.; Tawfik, A.; et al. EcoCity capacity building in NBC, a collaboration project between Finland and Egypt. In Proceedings of the SB13 Cairo Conference: Democratic Transition and Sustainable Communities, Cairo, Egypt, 6-7 November 2013.

17. Jantsch, E. Perspective of planning. Technol. Forecast. Soc. Chang. 1971, 2, 339-341.

18. Linstone, H.; Turoff, M. Delphi: A brief look backward and forward. Technol. Forecast. Soc. Chang. 2011, 78, 1712-1719. [CrossRef]

19. Probert, D.; Radnor, M. Frontier Experiences from Industry-Academia Consortia. Res.-Technol. Manag. 2003, 46, 27-30. [CrossRef]

20. Galvin, R. Roadmapping-A practitioner's update. Technol. Forecast. Soc. Chang. 2005, 71, 101-103. [CrossRef] 
21. Kazi, A.; Wolf, P. Hands-on Knowledge Co-Creation and Sharing: Practical Methods and Techniques; Knowledge Board: Stuttgart, Germany, 2007.

22. Tuominen, P.; AbdelMonteleb, A.; Abd Elhafez, S.; Balbaa, O.; Dawoud, W.; Elboshy, B.; ElMahgary, Y.; Elkafoury, A.; Elshafei, G.; ElShazly, A.; et al. EcoCity Roadmap for Egypt. Actions for Eco-Efficient Urban Development; VTT Technology: Espoo, Finland, 2015; Volume 215, p. 36.

23. Hedman, Å.; Antuña Rozado, C.; Jantunen, J.; Tuominen, P.; Balbaa, O.; ElMahgary, Y.; ElShazly, A.; GamalEldin, M.; Hamza, A.; Kamel, A.; et al. Readiness for EcoCities in Egypt. Insights into the Current State of EcoCity Systems, Technologies and Concepts; VTT Technology: Espoo, Finland, 2014; Volume 161.

24. Abou-Zeid, A.; Bushraa, A.; Ezzat, M. Overview of feasibility study procedures for public construction projects in Arab countries. Eng. Sci. 2007, 18, 19-34. [CrossRef]

25. Justis, R.T.; Kreigsmann, B. The feasibility study as a tool for venture analysis. Bus. J. Small Bus. Manag. 1979, 17, 35-42.

26. Bryce, T. The Elements of a Good Feasibility Study. Project Smart Online Project Management Resource 2008. Available online: https:/ / www.projectsmart.co.uk (accessed on 11 February 2016).

27. Antuña Rozado, C.; Hedman, Å.; Tuominen, P.; Reda, F.; ElMahgary, Y.; ElShazly, A.; GamalEldin, M.; Kamel, A.; Negm, A.; Tawfik, A.; et al. EcoNBC Feasibility Study. Transforming New Bord El Arab into an EcoCity; VTT Technology: Espoo, Finland, 2015; Volume 220.

28. Reda, F.; Tuominen, P.; Hedman, Å.; Ibrahim, M.G.E. Low-energy residential buildings in New Borg El Arab: Simulation and survey based energy assessment. Energy Build. 2015, 93, 65-82. [CrossRef]

29. Tuominen, P.; Reda, F.; Dawoud, W.; Elboshy, B. Economic Appraisal of Energy Efficiency in Buildings Using Cost-effectiveness Assessment. Procedia Econ. Financ. 2015, 21, 422-430. [CrossRef]

30. Joss, S. Eco-Cities: The Mainstreaming of Urban Sustainability-Key Characteristics and Driving Factors. Int. J. Sustain. Dev. Plan. 2011, 6, 268-285. [CrossRef]

31. Barton, H. Sustainable Communities: The Potential for Eco-Neighbourhoods; Earthscan Publishers: London, UK, 2000.

32. Ormazábal, I.G.; García-Navarro, J.; Fernández Pérez, T. The influence of openings on energy demand of buildings: Analysis of their characteristic parameters using LIDER software (Spain). Int. J. Constr. Environ. 2013, 4, 41-57. [CrossRef]

33. Alonso Ruiz-Rivas, C.; Oteiza San José, I.; García Navarro, J.; Martín-Consuegra, F. Energy consumption to cool and heat experimental modules for the energy refurbishment of façades. Three case studies in Madrid. Energy Build. 2016, 126, 252-262. [CrossRef]

34. Joss, S.; Tomozeiu, D.; Cowley, R. Eco-city indicators: Governance challenges. WIT Trans. Ecol. Environ. 2012, 155, 109-120.

(C) 2016 by the authors; licensee MDPI, Basel, Switzerland. This article is an open access article distributed under the terms and conditions of the Creative Commons Attribution (CC-BY) license (http://creativecommons.org/licenses/by/4.0/). 